\title{
11-12 (III-IV GIMNAZIJOS) KLASIŲ MOKINIŲ SVEIKATOS RAŠTINGUMAS IR ALKOHOLIO VARTOJIMAS
}

\author{
Olga Ubartienė, Genė Šurkienė \\ Vilniaus universiteto Medicinos fakulteto Sveikatos mokslu institutas
}

Raktažodžiai: sveikatos raštingumas, alkoholio vartojimas, paaugliai, mokiniai.

\section{Santrauka}

Sveikatos raštingumas - svarbi visuomenès sveikatos sritis. Nepakankamas sveikatos raštingumo lygis gali lemti paauglių žalingą elgesị, turintị neigiamos įtakos jų sveikatai, todèl svarbu plètoti ir vertinti visuomenès sveikatos intervencijas, kurios galètų skatinti geresnị paaugliu ir jaunų žmonių sveikatos informacijos supratimą ir jos panaudojimą. Tyrimo tikslas - nustatyti 11-12 (III-IV gimnazijos) klasių mokinių alkoholio vartojimo ir sveikatos raštingumo sąsajas. Tyrimo metodai. Anoniminès anketinès apklausos metodu buvo apklausti 1038 Lietuvos mokyklų 11-12 (III-IV gimnazijos) klasių mokiniai. Sveikatos raštingumo lygiui ịvertinti buvo naudojamas HLS-EU-Q47 išsamus 47 klausimų sveikatos raštingumo klausimynas, išverstas ị lietuvių kalbą. Kita anketos dalis sudaryta iš socialinių-demografinių klausimų bei klausimų apie alkoholio vartojimą. Statistinè analizè buvo atlikta naudojant statistinių duomenų apdorojimo programas SPSS, Microsoft Excel ir WinPepi. Kategoriniu duomenų analizei buvo naudojamas $\chi^{2}$ kriterijus ir Fisher palyginimo testas. Dviems nepriklausomoms ranginèms imtims buvo naudotas Mann-Whitney U testas, o kelioms nepriklausomoms ranginėms imtims - KruskalWallis testas. Ryšiams tarp ranginių kintamujų nustatyti buvo naudojamas Spearman koreliacijos koeficientas (rs). Rezultatai. Daugiau kaip pusès (53,3 proc.) mokinių sveikatos raštingumo lygis buvo pakankamas arba puikus, o kas 10 mokinio - neadekvatus. Berniukų ir 11 (III gimnazijos) klasių mokinių sveikatos raštingumas blogesnis, nei mergaičių $(p<0.001)$ ir 12 (IV gimnazijos) klasių mokinių ( $\mathrm{p}<0.001)$. Beveik pusė mokinių vartojo alkoholi reguliariai (48,8 proc.), kelis kartus per metus alkoholi vartojo apie trečdalis mokinių (30,7 proc.), penktadalis (20,5 proc.) mokinių atsakè, kad niekada nevartoja alkoholio. Alkoholị vartojančiu vaikinų daugiau nei merginų $(\mathrm{p}<0.001)$. Nustatytos sąsajos tarp mokinių alkoholio vartojimo dažnumo ir sveikatos raštingumo. Dažniau alkoholi vartojančių mokinių sveikatos raštingumo lygis buvo žemesnis ( $r s=0,751, p<0,001)$.

\section{Ivadas}

Sveikatos raštingumas - svarbi visuomenès sveikatos sritis. Ypatingo dèmesio reikia paaugliams. Nepakankamas sveikatos raštingumo lygis gali lemti paauglių žalingą elgesí, turintį neigiamos ittakos jų sveikatai. Paauglių sveikatos raštingumo tyrimai vis dar besivystanti medicinos mokslo sritis, bet atlikti tyrimai leidžia daryti prielaidas, kad yra keletas nepriklausomų asociacijų tarp žemesnio raštingumo lygio ir blogesnio prevencinių programų supratimo, ribojančio galimybes naudotis prevencinèmis programomis [1].

Sveikatos raštingumas tai yra lygis, matuojamas ir vertinamas žmogaus sugebejimu gauti, apdoroti ir suprasti pagrindinę informaciją apie sveikatą ir paslaugas, reikalingą priimti tinkamus sveikatos sprendimus [2].

Pasaulio sveikatos organizacija (PSO) $1998 \mathrm{~m}$. sveikatos raštingumą apibūdino kaip kognityvinius ir visuomeninius igūdžius, lemiančius individų motyvaciją ir galimybę siekti, suprasti ir naudotis informacija visais būdais, kurie skatina ir palaiko gerą sveikatą [3].

Vaikų sveikatos statistikos duomenys rodo didejjantị sergančių vaikų skaičių. Kasmet šie rodikliai blogèja. Nustatyta, kad 2014-2018 m. sergančių vaikų skaičius padidejjo 1,4 procento. $2018 \mathrm{~m}$. penkios dažniausios ligos, kuriomis sirgo vaikai, išliko tokios pačios kaip ir 2014 m.: kvẻpavimo sistemos ligos; simptomai, požymiai ir nenormalūs klinikiniai bei laboratoriniai radiniai, neklasifikuojami kitur; akies ir jos priedinių organų ligos; sužalojimai, apsinuodijimai ir tam tikri išoriniu poveikiu padariniai; virškinimo sistemos ligos [4]. Mūsų šalies vaikai jaučiasi gerokai nelaimingesni, negu kitų Europos šalių vaikai, blogiau vertina savo sveikatą [5]. Galima manyti, kad viena svarbiausių priežasčių yra ta, kad ilgą laiką mūsų šalyje sveikos gyvensenos kompetencijos ugdymui nebuvo ir iki šiol nepakankamai skiriama dėmesio, 
neįvertinamas vaikų, paauglių ir jų tėvų sveikatos raštingumo lygis, o tai lemia blogesnę paauglių sveikatos būklę. Žemesnio sveikatos lygio paaugliai, sulaikę pilnametystès, ir susiduria su įvairiais iššūkiais sveikatos priežiūros sistemoje, tokiais kaip receptinių vaistų instrukcijų ir sveikatos priežiūros paslaugų teikèjų nurodymų supratimas, medicininių blankų pildymas, todèl jiems kyla didesnè sveikatos problemų rizika [6]. Daugelis paauglių tampa pilnamečiais būdami geros sveikatos, vis dèlto yra ir tokių, kurių sveikata bloga. Daugelio suaugusiujjų sunkių ligų priežastis yra paauglystès laikotarpio elgesys [7], todèl svarbu plètoti ir vertinti visuomenès sveikatos intervencijas, kurios galètų skatinti geresni paauglių ir jaunų žmonių sveikatos informacijos supratimą ir jos panaudojimą.

Alkoholio vartojimas - viena iš prioritetinių visuomenès sveikatos problemų pasaulyje. Nors alkoholi vartoja apytiksliai pusè pasaulio populiacijos, visuomenès sveikatos požiūriu alkoholis - trečia tarp svarbiausių blogos sveikatos ir ankstyvos mirties priežasčių, po per mažo naujagimių svorio ir nesaugių lytinių santykių (alkoholis yra papildomas jų rizikos veiksnys), rizikingesnè nei tabakas [8].

PSO Europos regionas pirmasis prièmė Alkoholio veiksmų planą (1992 m.). Trečioji Pasaulio sveikatos asamblèja $2010 \mathrm{~m}$. prièmé Pasaulinę žalingo alkoholio vartojimo mažinimo strategiją. Šešiasdešimt pirmajame PSO Europos regiono komiteto susitikime $2011 \mathrm{~m}$. rugsejjo mèn. šalys narès prièmė 2012-2020 metų Europos žalingo alkoholio vartojimo mažinimo strategiją [8].

Nuo 2006 metų Lietuvoje vykdoma Vyriausybès patvirtinta Alkoholio, tabako ir kitų psichiką veikiančių medžiagų vartojimo prevencijos programa [9]. Ši programa grindžiama bendradarbiavimu tarp mokyklos, šeimos ir ịvairių specialistų, o vykdoma remiantis pagrindiniais bendrosios (pirminès) prevencijos principais. Programos tikslas - ugdyti asmeni, motyvuotą sveikai gyventi, nevartoti alkoholio, tabako ir kitu psichiką veikiančių medžiagų. Ji pritaikyta kiekvienam amžiaus tarpsniui nuo ikimokyklinio iki vidurinio ugdymo.

Nors tarptautinès organizacijos jau ilgą laiką atkreipia dèmesi i grèsmingus alkoholio vartojimo rodiklius, visuomenejje vis dar gaji nuomonè, kad alkoholio vartojimas yra veikiau mažos visuomenès dalies (pačių geriančiųjų), nei šalia geriančiojo esančių asmenų sveikatos, gerovès ar, apskritai, šalies socialinè ir ekonominè problema [10]. Dèl tokios klaidinančios nuomonès labiausiai kenčia vaikai ir paaugliai, jų alkoholio vartojimo problema tampa panaši ị suaugusiujų [11]. Tyrimas rodo, kad kai kurie paaugliai pradeda vartoti alkoholį dèl klaidingo įsitikinimo, jog visi tai daro [12].

Alkoholio vartojimo sukeliamos žalos įvertinimo tyrimo autoriai vadovaujasi visuomenès sveikatos požiūriu, kuris alkoholio vartojimą vertina kaip rizikos veiksni, darantị didžiulę ịtaką tiek visuomenès socialinei gerovei, tiek ekonomikai ir jos tvarumui [10].

Naujausias tarptautinis vaikų sveikatos ir gyvensenos tyrimas (HBSC) ir alkoholio ir kitų psichoaktyvių medžiagų vartojimo Europos mokyklose tyrimas (ESPAD) rodo [5,13], kad daug Lietuvos mokyklinio amžiaus vaikų vartoja alkoholinius gèrimus.

PSO kas ketverius metus atlieka 5-9 klasių mokinių sveikatos ir gyvensenos tyrimą (HBSC). Naujausi rezultatai rodo, kad vienas iš šešių Lietuvos mokinių reguliariai vartoja alkoholinius gèrimus. Šis rodiklis - vienas prasčiausių Europoje [14]. 13-15 m. Lietuvos mokinių, kurie bent kelis kartus buvo apsvaigę nuo alkoholio (nes vartojo ji nesaikingai), dalis yra viena didžiausių Europoje ( $13 \mathrm{~m}$. berniukų - 16 proc. (šalių, kuriose atliktas HBSC tyrimas, vidurkis -6 proc.), $13 \mathrm{~m}$. mergaičiu -8 proc. (šaliu vidurkis -4 proc.), $15 \mathrm{~m}$. berniukų - 41 proc. (šalių vidurkis -24 proc.), mergaičiu 33 proc. (šalių vidurkis -20 proc.)). Alkoholio vartojimas tokiame jauname amžiuje gali labai pakenkti vaikų fiziniam ir protiniam vystymuisi. Kol jaunuolio smegenys dar galutinai nesusiformavusios, alkoholis gali jas lengvai pažeisti, o pažeidimai gali būti ilgalaikiai ir negrižtami [15].

Alkoholio ir kitų psichoaktyviųjų medžiagų vartojimo Europos mokyklose tyrimo (ESPAD), kuriame dalyvavo 35 Europos šalys, duomenimis, bent kartą gyvenime alkoholio ragavo 79 proc. tiek Lietuvos, tiek visų ESPAD 15-16 amžiaus mokinių $[13,16]$.

ESPAD tyrimo paskutiniojoje ataskaitoje nustatytos teigiamos tendencijos - bent kartą per pastarąsias 30 dienų iki apklausos alkoholį prisipažino vartoję 27 proc. Lietuvos 1516 metų mokinių (ESPAD 2011 - 63,2 proc.; ESPAD 2015 - 34 proc.), tai beveik dvigubai mažiau, nei kitose tyrime dalyvavusiose šalyse (šalių vidurkis 47 proc.). Alkoholio vartojimo tarp Lietuvos mokinių rodikliai nuolat gerèjo nuo 2003 metų, bet vis tiek rezultatai išlieka gana aukšti $[13,16]$.

2020 m. mokyklinio amžiaus vaikų gyvensenos tyrimo duomenimis, mokyklinio amžiaus 5, 7 ir 9 (I gimnazijų) klasių mokinių, kurie per patarąsias 30 dienų bent kartą vartojo alkoholinius gèrimus, buvo 10,6 proc. (atitinkamai 4,1 proc., 8,1 proc. ir 20,4 proc.) [17].

Apibendrinant galima teigti, kad ne tik suaugusiujų, bet ir vaiku alkoholio vartojimas Lietuvoje vis dar yra gana opi problema. Galima teigti, jog absoliuti dauguma pradeda vartoti alkoholinius gèrimus dar paauglysteje, nesuvokdami pasekmių. Taigi, ne tik vaikų sveikatos rodikliai, bet ir jų gyvensena rodo, kad labai svarbu didinti vaikų ir paaugliu sveikatos raštingumą.

Mokslinių tyrimų apie vaikų ir paauglių sveikatos raštingumą labai mažai $[18,19]$ ir nerasta nei vieno tyrimo apie 17- 
19 metų paauglių, kurių didžioji dalis mokosi 11-12 klasėse, sveikatos raštingumo lygio ir alkoholio vartojimo sąsajas.

Tyrimo tikslas - nustatyti Lietuvos mokyklų 11-12 (III-IV gimnazijos) klasių mokinių alkoholio vartojimo ir sveikatos raštingumo sąsajas.

\section{Tyrimo medžiaga ir metodai}

Tyrimo imtis buvo sudaryta iš Lietuvos mokyklų 11-12 (III-IV gimnazijos) klasių mokinių, kurie savo noru sutiko dalyvauti tyrime.

Imtis sudaryta sankaupos (klasterinès) atrankos būdu (tikimybinè atranka), atrankos vienetas (klasteris) buvo klasè. Siekta, kad atrinktieji atstovautų Lietuvos moksleiviams pagal lytị, amžių ir gyvenamają vietą. Buvo apskaičiuotas visų Lietuvos gimnazijų III-IV klasių ir pagrindinių bei vidurinių mokyklų 11-12 klasių skaičius, sudaroma klasterių numerinè eilès tvarka kiekvienai gimnazijai (mokyklai) ir, panaudojant atsitiktinių skaičių lenteles, atrinkta 40 klasių. Tokia imtis pakankamai reprezentuoja Lietuvos 11-12 (III-IV gimnazijos) klasių mokinių populiaciją.

Anoniminès anketinès apklausos metodu buvo apklausti 1038 mokiniai. Sveikatos raštingumo lygiui ịvertinti buvo naudojamas HLS-EU-Q47 išsamus 47 klausimų sveikatos raštingumo klausimynas, išverstas ị lietuvių kalbą [20, 21]. Šis instrumentas pasirinktas dèl jo tinkamumo tirti paauglius nuo 13 metų. Kita anketos dalis sudaryta tyrèjų, i kurią ièjo socialiniai - demografiniai klausimai ir klausimai apie alkoholio vartojimą. Klausimynas išbandytas bandomojo tyrimo metu ir koreguotas, atsižvelgiant ị šio tyrimo rezultatus.

Mokinių apklausa buvo atliekama klasėse pamokų metu. Apklausos dieną mokykloje esantys mokiniai anketas pilde savarankiškai, anketų pildymo laikas apie 20 minučių. Apklausos dalyvių asmeniniai duomenys anketose nenurodyti. Medicinos kortelių duomenys tyrimui nebuvo naudojami. Visi atsakymų duomenys buvo koduojami ir suvedami $i$ tam tikslui sudarytą duomenų bazę. Analizuojant duomenis, jie buvo apibendrinami visiems tiriamiesiems, rezultatai skelbiami išlaikant tiriamujų anonimiškumą ir konfidencialumą. Tyrimui buvo gautas Vilniaus regioninio biomedicininių tyrimų etikos komiteto leidimas (2016-02-09 Nr.15820016-836-343).

Sveikatos raštingumui vertinti naudoti 47 klausimai.

1 lentelè. Respondentų charakteristikos

\begin{tabular}{|l|c|c|c|c|c|c|}
\hline \multirow{2}{*}{ Klase் } & \multicolumn{2}{|c|}{$\begin{array}{c}\text { Vaikinai } \\
\text { (N=490) }\end{array}$} & \multicolumn{2}{c|}{$\begin{array}{c}\text { Merginos } \\
\text { (N=532) }\end{array}$} & \multicolumn{2}{c|}{$\begin{array}{c}\text { Visi } \\
(\mathbf{N = 1 0 2 2})\end{array}$} \\
\cline { 2 - 7 } & $\mathrm{N}$ & $\%$ & $\mathrm{~N}$ & $\%$ & $\mathrm{~N}$ & $\%$ \\
\hline $11(\mathrm{III})$ & 278 & 56,7 & 273 & 51,3 & 551 & 53,9 \\
\hline $12(\mathrm{IV})$ & 212 & 43,3 & 259 & 48,7 & 471 & 46,1 \\
\hline
\end{tabular}

Mokinių atsakymai į klausimus, skirtus įvertinti jų sveikatos raštingumą, matuoti pasirinkta rangine skale: 1 - labai sunku, 2 - sunku, 3 - lengva, 4 - labai lengva. Respondentai galejo pasirinkti ir atsakymą 5 - nežinau. Analizei buvo atrinkti tie respondentai, kurie atsake į sveikatos raštingumo klausimus, pasirinkdami atsakymo variantus nuo 1 iki 4. Pasirinkę atsakymus „nežinau“, iš analizès buvo atmetami. Bendrasis sveikatos raštingumo indeksas skaičiuotas panaudojant atsakymų i 47 klausimus balus. Atsakymų balai buvo transformuojami taip, kad mažiausias balas būtų lygus 0 , o didžiausias -50 .

Sveikatos raštingumo indeksas skaičiuotas taip:

indeksas $=($ vidurkis -1$) \times(50 / 3)$, kur vidurkis - kiekvieno respondento atitinkamų klausimų vidurkiai,

1 - mažiausia galima vidurkio reikšmè (gaunama mažiausia indekso reikšmè - 0 ),

3 - vidurkių plotis,

50 - pasirinkta maksimali indekso reikšmè.

Apskaičiuotas indeksas suskirstytas i 4 kategorijas ir vertinamas sveikatos raštingumo lygis: $0-25$ balai - neadekvatus raštingumas; 26-33 balai - probleminis raštingumas; 34-42 balai - pakankamas raštingumas; $43-50$ balai - puikus raštingumas $[19,20]$. Statistinè analizè atlikta naudojant statistinių duomenų apdorojimo programas SPSS, Microsoft Excel ir WinPepi. Kategorinių duomenų analizei buvo naudojamas $\chi^{2}$ kriterijus ir Fišer palyginimo testas. Dviems nepriklausomoms ranginems imtims naudotas Mann-Whitney $\mathrm{U}$ testas, o kelioms nepriklausomoms ranginems imtims - Kruskal-Wallis testas. Ryšiams tarp ranginių kintamujų nustatyti buvo naudojamas Spearman koreliacijos koeficientas (rs). Koreliacijos koeficiento verčių skalè: 0 - ryšio nėra, nuo 0 iki 0,2 - labai silpnas ryšys, nuo 0,2 iki 0,5 - silpnas, nuo 0,5 iki 0,7 - vidutinis, nuo 0,7 iki 1 - stiprus, 1 - labai stiprus ryšys. Tyrimo rezultatų skirtumai laikyti statistiškai reikšmingi, kai $\mathrm{p} \leq 0,05$.

\section{Rezultatai ir jų aptarimas}

Tyrime dalyvavo 1022 11-12 (III-IV gimnazijos) klasių mokiniai, iš jų 532 (52 proc.) merginos ir 490 (48 proc.) vaikinų (1 lentelè).

Siekta įvertinti mokinių sveikatos raštingumo lygị, alkoholio vartojimo dažnumą ir nustatyti, ar yra ryšys tarp mokinių alkoholio vartojimo dažnumo ir jų sveikatos raštingumo.

Mūsų tyrimo duomenimis, daugiau kaip pusès (53,3 proc.) mokinių sveikatos raštingumo lygis buvo pakankamas arba puikus, o kas 10 mokinio - neadekvatus (1 pav.). Daugiau 12 (IV) nei 11 (III) klasių mokinių sveikatos raštingumas buvo pakankamas arba puikus, atitinkamai 68,6 proc. ir 41,4 proc. $(\mathrm{p}<0,001)$. Vertinant sveikatos raštingumą pagal respondentų lytị nustatyta, kad mergaičių, kurių sveikatos 
raštingumas yra probleminis, buvo mažiau, nei berniuku 28,9 proc. ir 45,4 proc. atitinkamai $(\mathrm{p}<0,001)$.

Kitų autorių tyrimų rezultatai skiriasi nuo mūsų: žemas sveikatos raštingumas nustatytas 12,1 proc. $7-10$ klasių mokinių, 70,5 proc. mokinių nustatytas vidutinis ir 17,4 proc. - aukštas sveikatos raštingumas [18]. Mūsų tyrimo rezultatai šiek tiek geresni: 11-12 klasių 9,5 proc. mokinių sveikatos raštingumas žemas ir 20,4 proc. - puikus. Mūsų tyrimo rezul-

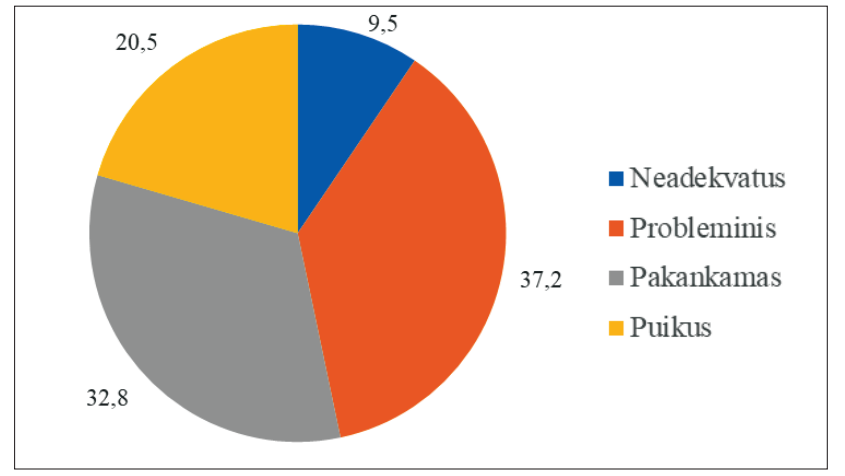

1 pav. Mokinių sveikatos raštingumo lygis (proc.)

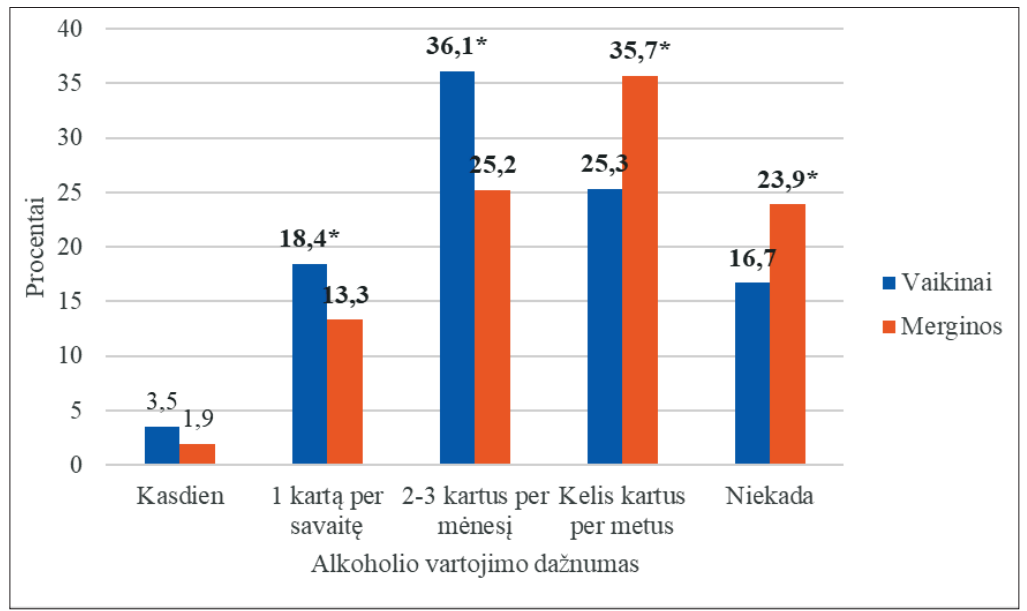

2 pav. Alkoholio vartojimo dažnumas pagal lyti (proc.) $\left(\mathrm{X}^{2}=31,892, \mathrm{p}<0,001\right)$ $*_{p}<0,001$

2 lentelè. Mokinių alkoholio vartojimo dažnumas, atsižvelgiant ị sveikatos raštingumo lygi $r=0,751, p<0,001$

\begin{tabular}{|c|c|c|c|c|c|}
\hline \multirow[t]{2}{*}{ Klausimas } & \multirow[t]{2}{*}{ Atsakymo variantas } & \multicolumn{4}{|c|}{ Sveikatos raštingumas } \\
\hline & & $\begin{array}{c}\text { vidutinis } \\
\text { rangas }\end{array}$ & $\chi^{2}$ & df & p \\
\hline \multirow{5}{*}{\begin{tabular}{|l|} 
Ar vartoji \\
alkoholinius \\
gėrimus?
\end{tabular}} & Kasdien & 49,50 & \multirow{5}{*}{578,815} & \multirow{5}{*}{4} & \multirow{5}{*}{$<0,001$} \\
\hline & Kelis kartus per metus & 224,15 & & & \\
\hline & 2-3 kartus per mėnesi & 395,34 & & & \\
\hline & 1 kartą per savaitę & 611,66 & & & \\
\hline & Niekada & 814,19 & & & \\
\hline
\end{tabular}

tatai galëjo būti geresni dèl to, kad jame dalyvavo vyresnio amžiaus mokiniai, o sveikatos raštingumui vertinti naudota skirtinga priemonè.

Analizuojant mokinių alkoholio vartojimo dažnumą nustatyta, kad beveik pusè mokinių vartojo alkoholį reguliariai ( 48,8 proc.), kelis kartus per metus vartojo apie trečdalis mokinių (30,7 proc.), penktadalis (20,5 proc.) atsake, kad niekada nevartojo alkoholio. Net 15,8 proc. mokiniu alkoholinius gėrimus vartojo kartą per savaitę, tokių vaikinu statistiškai reikšmingai daugiau nei merginų, atitinkamai 18,4 proc. ir 13,3 proc. $(\mathrm{p}<0,001)$. Kasdien vartojančiu alkoholi vaikinų buvo daugiau nei merginų, atitinkamai 3,5 proc. ir 1,9 proc., tačiau šis skirtumas nebuvo statistiškai reikšmingas $(\mathrm{p}=0,113)$. Visiškai nevartojančių alkoholio merginų statistiškai reikšmingai daugiau nei berniukų (2 pav.), atitinkamai 23,9 proc. ir $16,7(\mathrm{p}<0,001)$.

Panašius duomenis gavo ir kito tyrimo autoriai, kurie vertino 14-19 metų mokinių alkoholinių gėrimų vartojimo ypatumus ir motyvaciją, ir nustate, kad alkoholinius gèrimus ịvairiu dažnumu vartojo 75,9 proc. moksleivių, kelis kartus per metus svaigiuosius gèrimus vartojo 29,2 proc. respondentų [22].

I. Lenčiauskienès ir A. Zaborskio Lietuvoje atlikto tyrimu duomenimis, taip pat beveik pusė ( 43,8 proc.) penkiolikos metų moksleivių alkoholinius gèrimus vartoja reguliariai [23]. Kito tyrimo duomenimis, 71,1 proc. 9-12 klasių moksleivių skirtingais dažniais vartoja skirtingos rūšies alkoholị [24]. Kiti gyvensenos tyrimai taip pat rodo gan aukštą alkoholinių gérimų vartojimo paplitimą vaikų ir paauglių tarpe.

Pagal HBSC tyrimo rezultatus, 74 proc. 15 metų mergaičiu ir 67 proc. 15 metų berniukų nors kartą gyvenime vartojo alkoholị. Per pastarąsias 30 dienų alkoholị vartojo 34 proc. mergaičių ir 31 proc. berniukų. Mūsų tyrimo duomenimis, alkoholị vartojančių vaikinų daugiau: 83,3 proc. vaikinų ir 76,1 merginų alkoholi vartoja reguliariai arba kartais [5]. Šie skirtumai gali būti susiję su tuo, kad mūsų tyrime dalyvavo vyresnio amžiaus mokiniai ir dèl skirtingo mokinių alkoholio vartojimo dažnumo grupavimo.

Alkoholio ir kitų narkotikų vartojimo Europos mokyklose tyrimas parodè, bent karta gyvenime alkoholio ragavo 79 proc. $15-16$ metų mokinių. Šio, kaip ir mūsų tyrimo duomenimis, mergaičių, vartojusių alkoholị, daugiau nei berniukų. Pasak tyrejų, 83 proc. 
mergaičių ir 75 proc. berniukų nors kartą gyvenime vartojo alkoholį. Per pastarąsias 30 dienų alkoholi vartojo 30 proc. mergaičių ir 24 proc. berniukų [13]. Šie skirtumai taip pat gali būti susiję su tuo, kad mūsų tyrime dalyvavo vyresnio amžiaus mokiniai.

Vertinant mokinių alkoholio vartojimo dažnumą, atsižvelgiant ị sveikatos raštingumo lygị, nustatytas tiesioginis ryšys.

Dažniau alkoholi vartojančių mokinių sveikatos raštingumo lygis buvo žemesnis, palyginus su vartojančiais rečiau arba nevartojančiais alkoholio mokiniais. Tarp dviejų požymių nustatytas statistiškai reikšmingas stiprus tiesioginis ryšys $\left(\mathrm{r}_{\mathrm{s}}=0,751, \mathrm{p}=<0.001\right)$ (2 lentelè). Labai panašaus stiprumo koreliacinis ryšys tarp sveikatos raštingumo ir alkoholio vartojimo gautas lyginant šiuos rodiklius atskirai tarp merginu $\left(r_{s}=0,749, p=<0.001\right)$ ir tarp vaikinų $\left(r_{s}=0,752, p=<0.001\right)$

Mūsų tyrimo rezultatai panašūs ị kitų tyrējų rezultatus. Pasak kitų tyrèjų, žemas vaikų sveikatos raštingumas susijęs su rūkymu, alkoholio vartojimu, nutukimo rizika, prastesniu savo sveikatos vertinimu bei žemesne savigarba. Tyrimų duomenimis nustatyta, kad suaugusieji, kurių aukštas sveikatos raštingumo lygis, rečiau vartoja alkoholinius gèrimus [25].

Kitų tyrimų rezultatai taip pat parodẻ statistiškai reikšmingą ryši tarp alkoholio vartojimo ir sveikatos raštingumo lygio. Mokiniai, kurių sveikatos raštingumo lygis nepakankamas, alkoholinius gèrimus vartojo dažniau, nei tie, kurių sveikatos raštingumas buvo pakankamas (atitinkamai 91,7 ir 83,3 proc., $\mathrm{p}<0,05)$ [18].

Pasak kitų tyrimų autorių, nustatytas ryšis tarp netinkamo, dažno ir probleminio alkoholio vartojimo ir nepakankamo sveikatos raštingumo [25-27].

Šis ryšys atskleidžia, kad nepakankamas sveikatos raštingumo lygis gali lemti žalingą sveikatos elgesị, kuris gali prisidèti prie sveikatos būklès pablogèjimo, o žalingas elgesys gali lemti nepakankamą sveikatos raštingumo lygị. Paauglių sveikatos raštingumo tyrimai vis dar besivystanti medicinos sritis, bet jau galima daryti prielaidas, kad yra ryšys tarp žemesnio sveikatos raštingumo lygio ir blogesnio prevencinių programų supratimo, ribojančio galimybes naudotis prevencinėmis programomis [1]

Mūsų tyrimo duomenys parodè, kad mokinių alkoholio vartojimas išlieka reikšminga visuomenès sveikatos problema ir stipriai koreliuoja su sveikatos raštingumu.

\section{Išvados}

1. Daugiau kaip pusès mokinių sveikatos raštingumo lygis buvo pakankamas arba puikus. Vaikinų sveikatos raštingumas blogesnis nei merginų; dvyliktokų sveikatos raštingumas geresnis, nei vienuoliktokų.

2. Beveik pusè mokinių vartojo alkoholį reguliariai. 16 proc. mokiniu alkoholinius gèrimus vartojo kartą per savaitę.
Vaikinai alkoholi vartojo dažniau, nei merginos.

3. Nustatytos sąsajos tarp mokinių alkoholio vartojimo dažnumo ir sveikatos raštingumo: alkoholị dažniau vartojusių mokinių sveikatos raštingumo lygis buvo žemesnis, palyginus su vartojančiais rečiau, arba visai nevartojančiais alkoholio mokiniais.

\section{Literatūra}

1. Chisolm DJ, Manganello JA, Kelleher KJ, Marshal MP. Health literacy, alcohol expectancies, and alcohol use behaviors in teens. Patient Educ Couns 2014;97(2):291-296.

https://doi.org/10.1016/j.pec.2014.07.019

2. Institute of Medicine. Health literacy: a prescription to end confusion. The National Academies Press; Washington, DC: 2004.

3. Health promotion glossary. World Health Organization 1998:10.

4. Našlènė Ž., Petrauskaitė I., Želvienė A. Lietuvos vaikų sveikatos būklès pokyčiai ir netolygumai. Vilnius: Higienos institutas, 2020:85.

5. Spotlight on adolescent health and well-being: findings from the 2017/2018 Health Behaviour in School-aged Children (HBSC) survey in Europe and Canada. http://www.hbsc.org/ publications/international/

6. Health literacy and adolescents: a framework and agenda for future research. Manganello JA Health Educ Res 2008;23(5):840-7. https://doi.org/10.1093/her/cym069

7. Adolescent health. http://www.searo.who.int/topics/adolescent_health/en/

8. Alkoholis Europos Sajungoje. Vartojimas, žala ir politikos priemonės. https://www.ntakk.lt/wp-content/uploads/Alcohol_in_EU_LT.pdf

9. Alkoholio, tabako ir kitų psichiką veikiančių medžiagų vartojimo prevencijos programa. Lietuvos Respublikos švietimo ir mokslo ministro 2006 m. kovo 17 d. ịsakymas Nr. ISAK-494.

10. Alkoholio vartojimo sąlygojamas žalos Lietuvoje skaičiavimo metodikos parengimas ir žalos ịvertinimas $2015 \mathrm{~m}$. ir $2016 \mathrm{~m}$. https://www.lsmuni.lt/media/dynamic/files/16349/alkoholio_ zalos tyrimas.pdf

11. Čaikinienė I. Apklausa Alkoholio vartojimo paplitimas tarp jaunimo. Panevėžio miesto savivaldybès visuomenès sveikatos biuras, 2016.

12. Vadovas tėvams apie paauglių alkoholio vartojimą. http:// siauliurvsb.lt/uploads/files/Vadovas $\% 20 \mathrm{t} \% \mathrm{C} 4 \% 97 \mathrm{vams} \% 20$ a p i e $\% 20$ pa aug 1 i \% C $5 \%$ B $3 \% 20$ a 1 k oh o 1 i o $\% 20$ vartojim $\% \mathrm{C} 4 \% 85$.pdf

13. ESPAD report 2019 results from the European school survey project on alcohol and other drugs.

http://www.espad.org/sites/espad.org/files/2020.3878_EN_04. pdf

14. Vis dažnesnis alkoholio vartojimas tarp paauglių: vertina kaip maištą. Prieiga per internetą:

https://www.lrt.lt/naujienos/lietuvoje/2/1059499/vis-daznesnis- 
alkoholio-vartojimas-tarp-paaugliu-vertina-kaip-maista

15. Alkoholis. http://195.182.85.232/failai/Informacija $\% 20$ mokykloms/Alkoholis/A\%20L\%20K\%20O\%20H\%20O\%20 L\%20I\%20S.pdf

16. Naujausias tyrimas: alkoholio vartojimas tarp paauglių mažiausias per 25 metus.

https://sam.lrv.lt/lt/naujienos/naujausias-tyrimas-alkoholiovartojimas-tarp-paaugliu-maziausias-per-25-metus

17. Lietuvos higienos institutas. Mokyklinio amžiaus vaikų gyvensenos tyrimas. 2020. https://hi.lt/uploads/pdf/tyrimai/2020/2020_vaiku_gyvensenos_rodikliu_suvestine-ataskaita.pdf

18. Augustanavičienè O. Moksleivių sveikatos raštingumo ir gyvensenos sąsajos. Magistro darbas. Kaunas: LSMU, 2011.

19. Sukys S, Trinkuniene L, Tilindiene I. Subjective health literacy among school-aged children: first evidence from Lithuania. Int J Environ Res Public Health 2019;16(18):3397.

https://doi.org/10.3390/ijerph16183397

20. HLS-EU Consortium: comparative report of health literacy in eight EU member states. The European health literacy survey LLSEU. 2012. https://www.healthliteracyeurope.net/hls-eu

21. Javtokas Z., Žagminas K., Žeromskienė D. Gyventojų sveikatos raštingumo vertinimas. Metodiniai patarimai. Vilnius, Sveikatos mokymo ir lygų prevencijos centras. Vilniaus universiteto medicinos fakulteto sveikatos mokslų institutas. 2019. http:// www.smlpc.1t/media/image/Naujienoms/2017\%20metai/ Lankstukai/Sveikatos_rastingumo_vertinimas. $\% 202017 \% 20$ (1).pdf

22. Baranauskas J. Alkoholinių gėrimų vartojimo ypatumai jaunų žmonių tarpe. Magistro darbas. Kaunas: LSMU, 2019.

23. Lenčiauskienė I., Zaborskis A. Rizikinga paauglių elgsena ir jos sąsajos su mokyklos aplinkos veiksniais. Visuomenès sveikata, 2007;3(38):24-29.

24. Maziliauskaitė E. Marijampolès apskrities profesinio rengimo centro moksleivių gyvensena. Magistro darbas. Vilnius: Vilniaus universitetas, 2017.

25. Wolf M, Gazmariarian J, Baker WD. Health literacy and health risk behaviors among older adults. Am J Prev Med 2007;32(1):19-24.

https://doi.org/10.1016/j.amepre.2006.08.024

26. Hawthorne G. Preteenage drug use in Australia: the key predictors and school-based drug education. J Adolesc Health 1997;20:384-95.

https://doi.org/10.1016/S1054-139X(96)00181-4

27. Hasking P, Shortell C, Machalek M. University students' knowledge of alcoholic drinks and their perception of alcohol-related harm. J Drug Educ 2005; 35(2):95-109.

https://doi.org/10.2190/9Y34-F5XR-AQV5-KEL8

\section{HEALTH LITERACY AND ALCOHOL CONSUPTION OF 11-12 (III-IV GYMNASIUM) GRADES SCHOOLCHILDREN \\ O. Ubartienė, G. Šurkienė}

Keywords: health literacy, adolescent, schoolchildren, health, alcohol, health behaviour, addictions.

Summary

Background. Health literacy is an important area in public health. Limited adolescent health literacy is linked to worse health outcomes and can lead to harmful behaviours affecting their health. Therefore, it is important to develop and evaluate interventions that can promote a greater understanding and using health information for adolescent.

The aim of the study: To assess health literacy level and alcohol consumption of 11-12 (III-IV gymnasium) grades schoolchildren.

Methods. Schoolchildren were questioned using anonymous survey method. The HLS-EU-Q47 comprehensive health literacy questionnaire of 47 items, translated into Lithuanian language, has been used to assess health literacy level. The respondents were also asked about socio-demographic characteristics, alcohol using and other factors, which can be associated with health literacy. The statistical analysis were performed using the statistical data processing program SPSS, Microsoft Excel and WinPepi. Chi-square criterion $\left(\chi^{2}\right)$ and Fisher's comparison test were used for categorical data analysis. For two unrelated ranked samples, the Mann - Whitney $U$ test was used, and for several unrelated ranked samples, the Kruskal - Wallis test was used. Spearman correlation coefficient (rs) was used to determine the relationships between rank variables. Scale of correlation coefficient values: 0 - no relationship, 0 to 0.2 - very weak relationship, 0.2 to 0.5 - weak, 0.5 to 0.7 - medium, 0,7 to 1 - strong, 1 - very strong relationship. The reliability coefficient of the survey was $\mathrm{p}<0,05$.

Results. The data showed that more than half $(53.3 \%)$ of schoolchildren manifested sufficient or excellent level of health literacy and almost every tenth schoolchildren has low health literacy. The health literacy was lower for boys than for girls $(\mathrm{p}<0.001)$, and lower for 11 th graders than for 12 th graders $(p<0.001)$. Almost half of students drink alcohol regularly $(48.8 \%)$, about a third of students $(30.7 \%)$ use it several times a year, and a fifth $(20.5 \%)$ of students said they never drink alcohol. More boys than girls consumed alcohol $(\mathrm{p}<0.001)$. Limited health literacy was associated with alcohol using. Those students who use alcohol more often have a lower level of health literacy ( $\mathrm{rs}=0.751, \mathrm{p}<0.001)$.

Conclusions. More than half of the schoolchildren manifested sufficient or excellent level of health literacy. The health literacy was lower for boys than for girls, and lower for 11th graders than for 12th graders. Almost half of students drink alcohol regularly. There are more boys drinking alcohol than girls. There is strong relationship between alcohol consumption and health literacy.

Correspondence to: olga.ubartiene@mf.vu.lt

Gauta 2021-03-05 